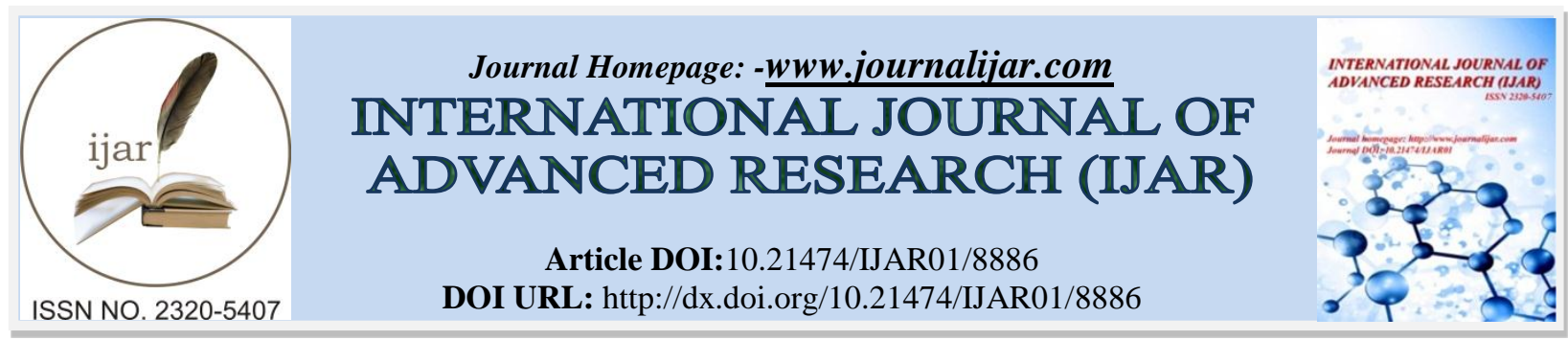

RESEARCH ARTICLE

\title{
THE EFFECT OF LOCUS OF CONTROL AND PROFESSIONALISM ON WHISTLEBLOWING INTENTION BY USING ORGANIZATION COMMITMENT AS THE MODERATING VARIABLE.
}

\section{Riana Anggraeny Ridwan ${ }^{1}$, Syarifuddin ${ }^{2}$ And Arifuddin ${ }^{2}$.}

1. Magister of Accounting, Faculty of Economics and Business, Hasanuddin University, Indonesia.

2. Department of Accounting, Faculty of Economics and Business, Hasanuddin University, Indonesia.

\section{Manuscript Info}

Manuscript History

Received: 11 February 2019

Final Accepted: 13 March 2019

Published: April 2019

Key words:-

locus of control, professionalism,

organizational commitment,

whistleblowing intention.

\section{Abstract}

This study aims to provide a review of the effect of locus of control and professionalism on whistleblowing intention and organization commitment as a moderating variable. The research object in this study was in the State Financial Controller (BPKP) West of Sulawesi. Total population was 97 auditors and the technique of determining the sample uses simple random sampling and the sample is choosen randomly regardless of the level in the member of the population with a total sample of 78 respondents. The data were analyzed using moderated regression analysis (MRA) by means of SPSS version 22 software.

The results of the research indicate that (1) locus of control has a positive and significant effect on whistleblowing intention; (2) professionalism has a positive and significant effect on whistleblowing intention; (3) organizational commitment moderates and strengthens the relationship of locus of control on whistleblowing intention; and (4) organizational commitment moderates and strengthens the relationship professionalism on whistleblowing intention.

Copy Right, IJAR, 2019,. All rights reserved.

\section{Introduction:-}

Along with the development of the times, the accountability of the performance of a government-owned institution is very important. Every agency that manages the lives of many people must provide accountability for its management. An international non-government survey institute that ranks countries as a barometer of global corruption and corruption perception index points to the following facts. "Indonesia in 2017 was ranked 96 out of 180 surveyed countries on the Corruption Perception Index (CPI) with a score of 37 out of 100, while in 2014 was ranked 107 out of 175 surveyed countries on the Corruption Perceptions Index (CPI) with a score 34 out of 100, (Transparency International, 2017). From this information, Indonesia has been steadily increasing for the past four years. Indonesia in 2017 ranked 96 out of 180 countries in the corruption perception index with a total score of 37 out of a total of 100 scores, while in 2014 Indonesia was ranked 107 out of 175 countries surveyed with a total score of 34 out of 100 . The ranking obtained was certainly not an achievement to be proud of. The predicate of a corrupt country certainly has a negative impact on people's welfare and also on development in Indonesia.

Based on survey data from ACFE in 2016, it was seen that corruption was the dominant factor that harms Indonesia by 77 percent compared to the misuse of state assets / wealth by 19 percent and fraudulent financial statements of 4

Corresponding Author:-Riana Anggraeny Ridwan.

Address:-Magister of Accounting, Faculty of Economics and Business, Hasanuddin University, Indonesia. 
percent. In addition, it was also found that government organizations were the organizations that were the most disadvantaged due to fraud, namely with a percentage of 81.2 percent compared to other organizations or institutions. The survey also shows that the best and most effective fraud prevention method is a whistleblowing mechanism.

Complaints from whistleblowers (as people call for whistleblowing) have proven to be more effective in uncovering fraud compared to other methods such as internal audit, internal control and external audit (Sweeney and Williams, 2008). This opinion is in line with the To To Nation Report published by the Association of Certified Fraud Examiners (ACFE) every two years placing the top ranking data on fraudulent sources. The importance of the existence of whistleblowing in uncovering fraud or financial scandals has been proven in the early decades of the twenty-first century (Dyck et. Al., 2010). The effectiveness of the whistleblower in disclosing cases of financial statement fraud is not only recognized by accountants and regulators in the United States, but also in other countries (Petel, 2003). Given the importance of the role of the whistleblower in disclosing fraud, an understanding of the factors underlying the intention to report fraud or misuse of assets is a very important topic (Aldred et al., 2007).

Today, whistleblowing has caught the world's attention, this is because many large companies commit fraud such as fraud, corruption, and other unethical actions that are finally revealed. Some of the big cases revealed were the cases of Enron, Worldcom, Anderson, and Tyco companies (Mesmer-Magnus and Viswesvaran, 2005). Some names listed as whistleblowers or people who report fraud or violations include: Chyntia Cooper for the case of the Worldcom company, Sharron Watkins for the case of the Enron company, Jeffrey Wigand for the cigarette company Brown \& Williamson Tobacco Corporation (Alleyne, et.al.: 2013 )

Not only abroad, fraud cases in Indonesia which were finally exposed, also happened to government institutions. This began with Susno Duadji's statement in the mass media regarding the practice of the legal mafia which dragged Gayus Tambunan. Gayus Tambunan is an employee of the Directorate General of Taxes involved in money laundering and corruption cases of tens of billions of rupiah. Susno Duadji's position in the structure of the Republic of Indonesia Police was actually very strong to reveal Gayus's case. However, due to the strong walls of solidarity between superiors and colleagues at the National Police Headquarters, Susno Duadji's report became completely incomplete. Until finally Susno Duadji reported the practice of fraud to outside parties such as the mass media and the Task Force for the Eradication of Legal Mafia (LPSK, 2011).

In the organization itself, one of the efforts that can be done in protecting organizations from parties who want to take personal or group profits is by conducting an internal audit. In minimizing and even eradicating fraud such as corruption in government bodies, the government makes internal control in the form of rules that are expected to help the government in monitoring the running of the government in this country, such as Government Regulation Number 79 of 2005 article 24 concerning supervision within the regional government by the Inspectorate General, Non-Departmental Government Institution Supervision Unit, Provincial Inspectorate and District / City Inspectorate.

Whistleblowing in government needs to be done because if you want to produce reliable audit quality, the internal auditor (BPKP) must have the courage to uncover all forms of fraud that exist in the organization because the parties who know the fraud the most are internal parties. The question is whether internal auditors have the courage to reveal all forms of fraud that occur? Because this will usually have an impact on the career, and the whistleblower actor will be moved, lowered his position, and will not get a promotion (James: 1984).

Several previous studies related to factors that influence the auditor's intention to do whistleblowing have revealed several determinants. Research conducted by (Winardi, 2013) using the framework of the theory of planned behavior to explain individual factors that form whistleblowing interests or intentions. Intention is the main predictor of behavior. The theory of planned behavior is a development of the behavior of the theory of reasoned action. Intention (intention) is assumed to capture motivational factors that influence behavior (Ajzen, 1991). Personality variables are variables that have a relationship with auditor behavior.

Characteristics of personality factors in question include locus of control and professionalism (Siegel and Marconi, 1989). Each individual has two components of locus of control, namely internal locus of control and external locus of control. However, in the decision-making process, only one locus of control will play a dominant role. Various types of research have provided empirical evidence relating to the influence of locus of control especially those with individual performance. An employee with a dominant internal locus of control tends to have better work results 
than employees with a level of tendency to external locus of control. However, if it is associated with the intention to do a whistleblowing the results are still varied. For example, research conducted by Jalil (2012) about the professional commitment of an auditor to whistleblowing intentions with locus of control as a moderating variable which turns out the results do not provide empirical evidence about the relationship of these variables. As with the research conducted by Chiu (2003), locus of control strengthens the relationship between ethical judgment and whistleblowing intentions. Hyatt and Prawitt's (2001) research states that for auditors from companies that tend to be unstructured, auditors will have a tendency towards internal locus of control (confidence that results are based on their behavior or input) perform better than auditors with locus of external control. The results of this study are reinforced by Kartika and Wijayanti (2007) who find that the auditor's individual characteristics significantly influence auditor performance. Auditors who have internal locus of control perform better than auditors who have external locus of control. Thus the locus of control variable used in this study is internal locus of control. Research conducted by Putri (2016) and Chiu (2013) found that locus of control had an effect on auditor behavior in conducting whistleblowing. Whereas the research conducted by Waroah (2016), Joneta (2016) found different results that locus of control did not affect auditor behavior in conducting whistleblowing.

Besides locus of control, other individual factors that influence auditor behavior in conducting whistleblowing are professionalism (attitude towards whistle-blowing) which, according to Sari and Laksito's research (2014), Kreshastuti and Prastiwi (2014) and Joneta (2016) have influence positive towards intention to take a whistleblowing action. In addition, research conducted by Jalil (2012) found that professionalism had no effect on the auditor's intention to carry out whistleblowing actions. Professionalism is an important variable for an auditor to do the best for the organization where he works. According to Yendrawati (2008: 76) professionalism is a concept to measure how auditors perceive their profession as reflected in their attitudes and behavior. To measure the level of professionalism is not only needed an indicator that states that people are said to be professional. In relation to the audit task process, each auditor is provided with binding rules and codes of ethics. An auditor has a big responsibility for the results of the audit. Auditors are required to be professional. All forms of pressure and intervention from the client should be used as a challenge in relation to work as an auditor.

In addition to individual factors, external factors that influence auditor behavior in conducting whistleblowing are organizational commitment. One of the benchmarks of the level of auditor professionalism is also seen based on its performance, while one individual factor that influences performance improvement is organizational commitment. Organizational commitment can be created if members of the organization are aware of their rights and obligations as members without seeing their position or individual position. Bariyima (2012) states that the success and performance of a person in a field of work is largely determined by how much organizational commitment he has. High organizational commitment will increase high performance (Randall and Gibson 1991).

Organizational commitment variable represents the subjective norm component in the theory of planned behavior. In this case the individual will think of a certain behavior very correctly because the actions and behavior that will be carried out will ultimately affect the judgment of others. In the context of accountants, these other people are companies, communities, and accountants' umbrella organizations themselves, namely the Indonesian Accountants Association (IAI) and also colleagues.

Organizational commitment is the strength of employees in accordance with how employees are involved in an organization, strong beliefs in the values and ultimate goals of an organization, as well as the willingness to try well on behalf of the organization (Porter, 1974). Someone who is indeed highly committed to the organization is likely to identify in advance in overcoming a situation that can endanger the organization in order to maintain the reputation and sustainability of the organization. Identification can get effects from other people's evaluations as well, for example colleagues. So the results of the identification can be subjective (more in favor of the organization or coworkers) or may be objective (see more cases that are happening). In addition, Aranya et. al (1981) states that professional commitment (accountants) involves professional beliefs, goals and values. There is a need to put in enough effort in the name of the profession and also the desire to maintain membership in the profession.

Based on the description stated earlier, this study was conducted to determine and analyze the influence of locus of control and professionalism on the intention of auditors to conduct whistleblowing moderated by organizational commitment. 


\section{Literature Review \\ Theory of Prosocial Behavior}

Prosocial behavior theory is behavior or action carried out by members of an organization towards certain individuals, groups or organizations aimed at improving the welfare of the group or organization. Brief and Motowidlo (1968) cited in Bagustianto (2013) say that prosocial behavior becomes a theory that supports the occurrence of whistleblowing because whistleblowing is an action that benefits the organization one of the 13 forms of prosocial organizational behavior. This is in line with the view that whistleblowing is prosocial behavior because in general the behavior will provide benefits to other people (organizations).

Prosocial behavior can be interpreted as behavior that benefits those who accept and does not have clear advantages for those who do it (Staub, 1978; Baron \& Byrne, 1994). Prosocial behavior is defined as behavior that changes the situation for the better, from the physical and psychological state of the recipient of the aid (William, 1981). More specifically, the notion of social behavior includes actions: Sharing (sharing), coorperative (cooperation), donating (donating), honesty (honesty), helping (helping), generoosity (generosity) and considering the rights and welfare of others (Eisenberg and Musen, 1989). Furthermore, Brigham (1991) explains that prosocial behavior is a behavior that makes other people prosperous. Staub (1978) classifies indicators of prosocial behavior, namely (1) the action ends in him and does not demand profit on the part of the perpetrator. (2) the action appears voluntarily, (3) the action produces goodness.

Based on the above constraints, it can be concluded that pro-social behavior is any form of behavior that has positive consequences for those who accept both physical and psychological forms but it does not have a clear advantage for the owner.

\section{Theory Of Planned Behavior}

Initially, this theory was called Theory of Reasoned Action (TRA), which is a theory aimed at studying and predicting individual behavior more specifically. This theory was put forward in 1975 by Fishbein and Ajzen. In 1985 this theory was then developed by Ajzen into the Theory of Planned Behavior (TPB). Ajzen argues that the main factor of an individual's main behavior is the Behavior Intention's individual intention towards a particular behavior. There are several goals and benefits of this theory, among others, to predict and understand the motivational influences on behavior that are not under the control or will of the individual. There are three components of intention to behave, namely (1) attitude, subjective norms, and perceptions of behavioral control (perceived behavior control).

In the theory of planned behavior, Ajzen (2005) suggests that perceptions of behavioral control are based on individual beliefs about compatibility, competence, resources in the form of tools, and opportunities (control belief strength) that support or inhibit predicted behavior and the role of these resources in realizing the behavior. The stronger and the greater the confidence that an individual has towards the availability of resources and opportunities that are owned in relation to certain behaviors, the stronger and the greater the individual's control over the behavior. To deepen understanding of attitude measurement, subjective norms, and behavioral control, first review the concept or its forming factors in the Theory of Planned Behavior.

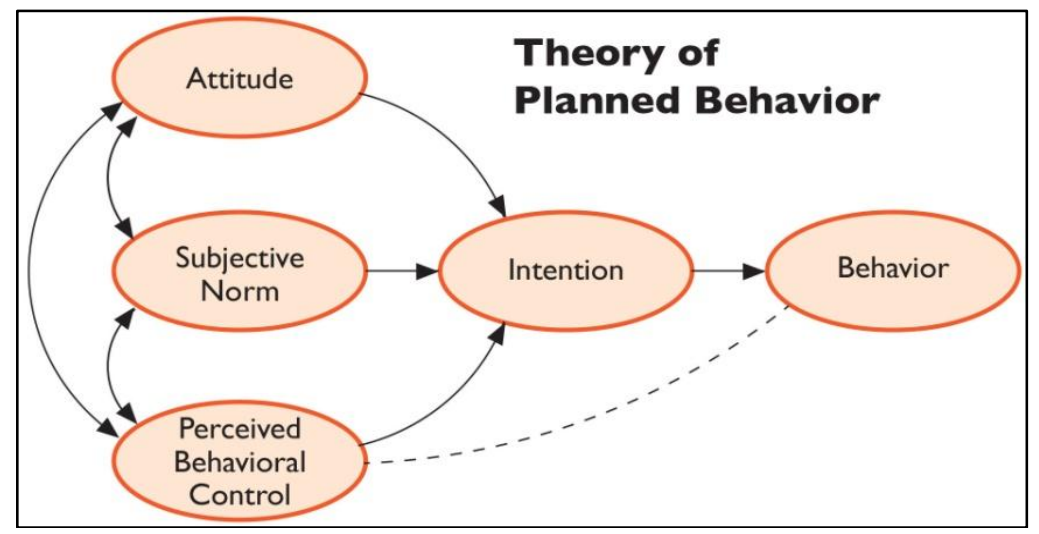

Gambar 1:-Theory of Planned Behavior 


\section{Locus of Control}

One of the personal characteristics that distinguishes one individual from another is the control center known as locus of control. Locus of control is a concept developed by Julian B. Rotter in 1966 where locus of control is that every individual builds expectations about their success depending on their behavior or on things that are outside of themselves (Alkautsar, 2014: 35-36 ) Gitosudarmo (2008: 21) argues that locus of control relates to the extent to which someone has confidence in what they do will affect the reward or reward that will be received. Robbin and Judge (2008: 138) also describe that locus of control is the level at which individuals believe that they are determinants of their own destiny.

\section{Profesionalism}

Arens et. al. (2009: 81) describes professionalism as a form of responsibility for behaving more than just fulfilling the responsibilities given to it and more than just complying with applicable laws and regulations in society. Professionalism is one of the main requirements for an auditor. As a state auditor, he should fulfill his responsibilities to the community, institutions, and his country. Kalbers and Fogaty (1995) distinguish professional concepts and professionalism where the profession is defined as the type of work that meets certain criteria while professionalism is an individual attribute that must be owned by someone without seeing a particular job or profession. The level of professionalism of a person can be assessed from the extent of the quality of the work or profession of the individual.

In general, there are three main categories for someone who is called a professional in his profession, namely having the expertise to carry out tasks in accordance with their fields, carrying out tasks or professions by setting standard standards in the relevant profession, and explaining his professional duties by adhering to established professional ethics.

\section{Organization Commitment}

Organizational commitment has many definitions and is measured in various different ways. Robbin and Judge (2011: 100) defines organizational commitment as follows: "Organizational commitment is the degree to which an employee identifies with a particular organization and its goals and wishes to maintain membership in the organization".

Kreitner and Kinicki (2000) state that organizational commitment is defined as how an individual identifies himself with an organization related to his goals, while Luthans (2006: 217) defines organizational commitment as a strong desire that employees have to maintain their position as members of the organization in which they work, the desire to try to be part of the organization, and a strong belief in the acceptance of the values and goals that exist within the organization. Organizational commitment is more than passive loyalty, but also involves an active relationship of the individual's desire to contribute fully to the organization.

\section{Whistleblowing}

Intention (intention) is the desire to do something / behavior (behavior). Intention refers to the individual's goal to carry out various types of actions and can be considered as specific reasons for trust. Someone will take an action if they have certain desires or intentions or interests to do so (Jogiyanto, 2007). Ajzen (2006) argues that the intention to take certain actions is an indication of an individual's tendency to behave and is an antecedent directly from the actor.

In the Theory of Planned Behavior, intention is influenced by three factors, namely Attitude Toward the Behavior, Subjective Norms, and Perceived Behavior Control. Intention is a tendency for someone to make a choice about the behavior that he will do or that is not done, because before doing something there is certainly an intention that arises in a person to do the act.

Bouville (2016) defines whistleblowing as an action of an employee (or ex-employee) to reveal something that he considers illegal or unethical to higher management / top management (Internal Whistleblowing) or to authorities / authorities outside the organization and to the public (external whistleblowing). While people who do whisteblowers are people who give information. Whistleblowing is an action that discloses information from a private or public organization to open dangerous corruption cases to the public (Kumar 2017) and Miceli and Near (1992) define whistleblowing as an act of reporting errors to individuals or organizations believed to have the power to stop it. 
Whistleblowers are generally good performers, highly dedicated to the organization, domicile as supervisors, and higher moral reasoning compared to an inactive fraud supervisor (Elias, 2008). However, disclosure of violations will generally pose a risk that is not desired by the disclosure of the violation, for example the threat of revenge and isolation at work.

\section{Hypothesis}

Referring to the various opinions above, the hypothesis of this study are: (a) locus of control has a positive effect on the intention of auditors to do whistleblowing, (b) professionalism has a positive and significant effect on the intention of auditors to do whistleblowing, (c) organizational commitment positively and significant in moderating the relationship between locus of control to the intention of auditors to do whistleblowing, and (d) organizational commitment has a positive and significant effect in moderating the relationship between professionalism and the intention of auditors to do whistleblowing.

\section{Research Methods:-}

Research design is a design of a research structure that directs processes and results that are valid, objective, efficient, and effective. The design of this study is hypothesis testing (hypotheses testing). The definition of hypothesis testing is a study described in the form of a statement accompanied by an explanation of the relationship that is estimated logically between two or more variables so that a solution can be found to overcome the problem at hand (Now, 2016: 83).

The type of data used in this study is primary data. Primary data is data obtained from the distribution of questionnaires (questionnaires) to respondents. The type of data used is quantitative data, namely the respondent's answer in the form of a score of each variable indicator obtained from filling out the questionnaire obtained from respondents. Questionnaires are arranged based on predetermined variables by attaching several alternative answers. The questionnaire given to respondents is a type of statement that is closed.

This research was carried out in government agencies, namely the Financial and Development Supervisory Agency (BPKP) of West Sulawesi Representatives, using simple random sampling techniques, namely research in which samples from members of the population were randomly carried out without regard to the strata (levels) of members of the population (now and Bougie, 2013). The number of samples taken in this study were 78 people.Definisi operasional variabel penelitian antara lain:

\section{Locus of Control}

Locus of control is defined as the extent to which contingencies between actions and the results they get, for someone who believes that they are in full control of their destiny called someone who has an internal locus of control, while those who believe that the results they get come from mixed other people's hands or other extrinsic factors outside of their control are called locus of external (Zoraifi, 2005).

\section{Profesionalism}

Professionalism is one of the attitudes of a person in doing a job or in carrying out a profession. There are five dimensions used in this study, namely: (a) professional service, (b) social obligations, (c) independence, (d) confidence in professional rules, and (e) relations with fellow professions.Komitmen Organisasi

\section{Organization Commitment}

Larkin (1990) argues that organizational commitment is a strength and identification of a person and about his involvement in a particular organization, while Weiner (1982) defines that organizational commitment is a motivation that comes from within him to be able to do something that can support success or positive impact in the success of the organization in accordance with its objectives and more focused on the interests of the organization. This variable is measured based on three components of the model developed by Mayer and Allen (1991), namely affective commitment, ongoing commitment, and normative commitment.Intensi Auditor Melakukan Whistleblowing

\section{Whistleblowing}

Hoffman and Robert (2008) describe the notion of whistleblowing as a disclosure made by employees regarding information that is alleged to contain legal violations, violations of rules, professional statements, or relating to 
procedural errors, corruption, abuse of authority, or that endanger the public and workplace safety. . This variable refers to the study of Brennan and Kelly (2007).

The analytical model used to test the hypothesis is by using Moderated Regression Analysis (MRA) with the help of SPSS version 22 software. This regression analysis is done in two stages of testing. The first stage is multiple regression without the moderation variable. The second stage and the third stage is a regression performed by the interaction between moderating variables and independent variables.

\section{Results And Discussion:-}

\section{Analysis Results}

Based on the results of the data analysis, it can be seen that the influence of locus of control and professionalism has a positive and significant effect on the auditor's intention to do whistleblowing. Furthermore, the influence of locus of control and professionalism on the auditor's intention to do a whistleblowing after being moderated by organizational commitment shows a positive and significant influence. This means that the moderating variable strengthens the influence of locus of control and professionalism on the auditor's intention to do whistleblowing.

Table 1:-Results of Multiple Linear Regression Analysis

\begin{tabular}{|c|c|c|c|c|c|}
\hline $\begin{array}{c}\text { Direct Relationship } \\
\text { Research Variable }\end{array}$ & $\begin{array}{c}\text { Regression } \\
\text { Coefficient }\end{array}$ & $\begin{array}{c}\text { Standard } \\
\text { Error }\end{array}$ & t-Statistics & Prob. & Explanation \\
\hline The constants & 6,717 & 3,237 & 2,075 & 0,042 & \\
\hline $\mathrm{X}_{1} \rightarrow \mathrm{Y}$ & 0,230 & 0,098 & 2,345 & 0,022 & Signifficant \\
\hline $\mathrm{X}_{2} \rightarrow \mathrm{Y}$ & 0,223 & 0,087 & 2,558 & 0,013 & Signifficant \\
\hline $\mathrm{R}^{2}$ & $=0,211$ & & & \\
\hline F Count & $=9,091$ & & & \\
\hline Sig. F Count & $=0,000$ &
\end{tabular}

\section{Source : Primary Data Processed, 2019}

The determination coefficient value of $\mathrm{R}$ square on the results of the above test shows a value of 0.211 or $21.10 \%$. These results indicate that the auditor's intention to do a whistleblowing variable is influenced by variables locus of control (X1) and professionalism (X2) of $21.10 \%$. The remaining $78.90 \%$ is influenced by other variables outside the independent variables examined in this study.

Locus of control (X1) variable obtained a probability value of 0.022 . Because the probability value is less than $5 \%$ $(0.022<0.050)$, then partially the locus of control variable (X1) has a significant effect on the auditor intention variable to do whistle-blowing $(\mathrm{Y})$. Based on the coefficient value of 0.230 it is positive, identifying its positive effect. This means that the higher the locus of control (X1), the higher the intention of the auditor to do a whistleblowing (Y). Conversely, the lower the locus of control (X1), the lower the auditor's intention to do a whistleblowing (Y).

Professionalism variable obtained a probability value of 0.013 . Because the probability value is less than $5 \%(0.013$ $<0.050$ ), then the professionalism variable (X2) partially has a significant effect on the auditor's intention to do whistleblowing (Y). Based on the coefficient value of 0.223 it is positive, identifying its positive effect. This means that the higher the professionalism (X2), the higher the intention of the auditor to do a whistleblowing (Y). Conversely, the lower the professionalism (X2), the lower the intention of the auditor to do a whistleblowing (Y).

Table 2:-Results of Moderate Regression Analysis Organizational Commitment to the Effect of Locus of Control on Auditor Intention to Do Whistleblowing

\begin{tabular}{|l|l|c|c|c|c|}
\hline \multicolumn{1}{|c|}{ Direct Variable } & $\begin{array}{c}\text { Regression } \\
\text { Coefficients }\end{array}$ & $\begin{array}{c}\text { Standard } \\
\text { Error }\end{array}$ & t-Statistics & Prob. & Explanation \\
\hline Constant & 0,206 & 3,958 & 0,052 & 0,959 & \\
\hline $\mathrm{Z}$ & 0,103 & 0,059 & 1,757 & 0,084 & \\
\hline $\mathrm{X}_{1} * \mathrm{Z} \rightarrow \mathrm{Y}$ & 0,005 & 0,001 & 3,925 & 0,000 & Significant \\
\hline $\mathrm{R}^{2}$ & $=0,428$ & & \\
\hline $\mathrm{F}$ Count & $=16,1456$ \\
\hline Sig. F count & $=0,000$ & & \\
\hline
\end{tabular}




\section{Source : Primary Data Processed, 2019}

The determination coefficient value of $\mathrm{R}$ square in the results of the above test shows a value of 0.428 or $42.8 \%$. These results indicate that the auditor's intention to do whistleblowing (Y) is influenced by $42.8 \%$ by locus of control (X1) after interacting with the variable organizational commitment (Z). The remaining $57.2 \%$ is influenced by other variables outside the independent variables examined in this study.

Locus of control variable interacts with organizational commitment (moderation) has a probability value of 0,000 below the value of the significance standard of 0.05 . This shows that organizational commitment moderates the influence of locus of control on the intention of auditors to do whistleblowing. The coefficient for interaction interaction variable locus of control and organizational commitment of 0.005 is positive, which means that organizational commitment variables strengthen the influence of locus of control on the intention of auditors to do whistleblowing.

Table 3:-Results of Moderate Regression Analysis Organizational Commitment to the Effect of Professionalism on the Auditor's Intention to Whistleblowing

\begin{tabular}{|l|c|c|c|c|c|}
\hline \multicolumn{1}{|c|}{ Direct variable } & $\begin{array}{c}\text { Regression } \\
\text { Coefficients }\end{array}$ & $\begin{array}{c}\text { Standard } \\
\text { Error }\end{array}$ & t-Statistics & Prob. & Explanation \\
\hline Konstanta & 10,876 & 4,199 & 2,590 & 0,012 & \\
\hline $\mathrm{Z}$ & 0,102 & 0,078 & 1,319 & 0,192 & \\
\hline $\mathrm{X}_{2} * \mathrm{Z} \rightarrow \mathrm{Y}$ & 0,003 & 0,001 & 2,259 & 0,027 & Significant \\
\hline $\mathrm{R}^{2}$ & $=0,326$ & & & \\
\hline $\mathrm{F}$ count & $=10,648$ & & & \\
\hline Sig. F count & $=0,000$
\end{tabular}

Source : Primary Data Processed, 2019

The determination coefficient value of $\mathrm{R}$ square in the results of the above test shows a value of 0.326 or $32.6 \%$. These results indicate that the auditor intention to do whistleblowing $(\mathrm{Y})$ is influenced by $32.6 \%$ by professionalism (X1) after interacting with the variable organizational commitment (Z). The remaining $67.4 \%$ is influenced by other variables outside the independent variables examined in this study.

Professionalism variables interact with organizational commitment (moderation) have a probability value of 0.027 below the value of the significance standard of 0.05 . This shows that organizational commitment moderates the effect of professionalism on the auditor's intention to do whistleblowing. The coefficient for interaction interaction variables professionalism and organizational commitment amounting to 0.003 is positive, which means that the organizational commitment variable strengthens the influence of professionalism on the auditor's intention to do whistleblowing.

\section{Discussion:-}

Effect of Locus of Control on the Auditor's Intention to Do Whistleblowing

The findings of this study indicate that locus of control influences the intention of auditors to conduct whistleblowing on auditors who work on the Financial Supervisory Agency and Development Representatives of West Sulawesi Province. The meaning is, the more confident an auditor is with himself then it will be followed by an increase in intention or intention to do whistleblowing. Conversely, if the auditor is increasingly not confident or the auditor has a weak locus of control, the auditor's intention to whistleblowing is also smaller.

The results of this study support the theory of planned behavior which assumes that perceived behavioral control has motivational implications for auditor intentions. Locus of control is part of the perceived behavioral control that can influence the intention of a person's behavior in behaving. This is consistent with the opinion of Rotter (1966) which states that locus o control is a person's belief in the sources that control the events in his life, namely whether the events that occur in him are controlled by external forces. Perceived control behavior is a factor that is believed by someone to support or hinder a person's behavior. 
The results of this study support the research conducted by Chiu (2002 and 2003) which found that locus of control and other variables, namely ethical considerations had a positive effect on auditor intentions in conducting whistleblowing, as well as research by Chadegani et. al (2015), found that locus of control positively and significantly influenced the auditor's intention to report errors. Conversely, the results of this study contradict Ahmad's (2011) research, which found that locus of control had no effect on the auditor's intention to do whistleblowing.Pengaruh Locus of Control Terhadap Intensi Auditor Melakukan Whistleblowing

\section{Effect of Locus of Control on the Auditor's Intention to Whistleblowing}

The findings of this study indicate that professionalism influences auditor intentions conduct whistleblowing on auditors working at the Financial Supervisory Agency and the Development of Representatives of West Sulawesi Province. It can be explained that the more professional the respondent is in carrying out his duties, the intention or intention of the auditor to make a complaint when carrying out his duties the auditor encounters an error then intends to report it through the mechanism of higher formal reporting (whistleblowing).

The results of this study are in accordance with the prosocial behavior theory developed by Eisenberg (1979) which suggests that a behavior or what is done by a member of the organization is intended to improve the welfare of the organization.

The results of this study support the research of Augusta (2015) and Maryadi (2018) which states that professionalism influences the intention of auditors to conduct whistleblowing. This reporting or whistleblowing action is important for auditors in carrying out their duties and functions as independent institutions that oversee government funds that protect the lives of many people (Intan, 2015).

Effect of Locus of Control on Auditor Intention To do Whistleblowing with Organization Commitment as moderating variables.

The results showed that organizational commitment had a positive and significant effect on moderating (strengthening) the influence of locus of control on auditor intentions in conducting whistleblowing auditors working at the Financial Supervisory Agency and Development Representatives of West Sulawesi Province.

The findings of this study are consistent with the opinion of Mowday et al. (1979) that organizational commitment is defined as the relative strength of individual identification and the degree of involvement with the organization. The findings of this study are confirmed by the opinion of Porter et al. (1974) who said that organizational commitment is characterized by several actions, among others, (1) trust, acceptance of values, and organizational goals, (2) willingness to exert considerable effort for the benefit of the organization, and (3) strong need to remain become part of the organization. This shows that the higher the level of organizational commitment an auditor has in carrying out his work, the intention or intention of the auditor to conduct a whistleblowing is higher, given that one of the mandatory attitudes of an auditor is to carry out the best possible duties and obey all rules that bind all forms of fraud that occur in order to optimize their role as institutions that oversee development in Indonesia.

In connection with the increasing organizational commitment of an auditor, this is in line with the theory of planned behavior that predicts how a person responds before doing something. One of the factors that drives humans before doing something, namely the tendency of the human mindset that considers the cause and effect he will receive when doing something (locus of control). Each individual has a different tendency to locus of control. If it is associated with the auditor's intention to conduct a whistleblowing, the locus of control which plays a dominant role is internal locus of control because internal locus of control tends to believe that everything that happens is a result of human behavior itself and not caused by others. Someone has full control over all the events that occur in his life. So, it can be concluded that the higher the level of organizational commitment someone has will strengthen the relationship between the direct influence of locus of control on the auditor's intention to conduct whistleblowing.

The results of this study are consistent with the research conducted by Bagustianto (2015) and Marga (2016) who found that organizational commitment has a positive and significant effect on the intention of auditors to conduct whistleblowing. On the other hand, the findings of this study contradict Agung's research (2017) which examined auditors working at the East Java Provincial Finance and Development Supervisory Agency who found that one of the variables was organizational commitment that had no influence on the auditor's intention to conduct whistleblowing. 


\section{Effect of Professionalism on Auditor Intention To do Whistleblowing with Organization Commitment as moderating variables.}

The findings of this study indicate that organizational commitment positively and significantly influences (strengthens) the influence of professionalism on auditor intentions in conducting whistleblowing auditors working at the Financial Supervisory Agency and the Development of Representatives of West Sulawesi Province.

Whistleblowing can be realized because of a good organizational environment. The creation of a good environment is also supported by the high professionalism that the auditor has. Professionalism and organizational commitment are two actions and attitudes that are in accordance with the prosocial behavior theory where the understanding of this theory is all forms of actions or attitudes of members of an organization that provide benefits for the organization to provide improved welfare for the group or organization. Professionalism is a reflection of the attitude of being responsible for a profession, bonding, loyalty, sacrifice the involvement of an individual in his organization (Anggun, 2010). The sense of professionalism possessed by an auditor is expected to be able to encourage the auditor to perform in accordance with the professional code of ethics that exists and uphold the values of norms and honesty in carrying out their work.

Some previous researchers found that professionalism had a positive and significant influence on the auditor's intention to conduct whistleblowing, as did research conducted by Dimas (2015) which found that the professionalism of Yogyakarta BPK auditors had a positive and significant influence on whistleblowing intentions. Likewise with the findings of Tria's (2016) research that professional commitment influences the intention to conduct whistleblowing. Furthermore, research conducted by Setiawati and Ratna Sari (2016) on the Effect of Auditor Professionalism and Organizational Commitment on Moral Intensity of Acting Accountants Conducting Whistleblowing, found that based on the tests conducted, professionalism and organizational commitment variables positively and significantly influence the auditor's intention to do whistleblowing. . Based on the results of the research that has been done, it can be concluded that the higher the organizational commitment possessed by an internal auditor working in the Financial Supervisory Agency and the Development of Representatives of West Sulawesi Province, it will strengthen the relationship between the auditor's intention to conduct whistleblowing.

\section{Conclution:-}

Based on the results of hypothesis testing and discussion of the effect of locus of control and professionalism on the auditor's intention to conduct whistleblowing moderated organizational commitment, conclusions can be drawn as follows:

1. Locus of control influences the auditor's intention to conduct whistleblowing. It can be interpreted that the higher the locus of control, the higher the intention of the auditor to do whistleblowing. This is in line with the theory of planned behavior which assumes that perceived behavioral control has motivational implications for the intention or intention of the auditor. Locus of control is part of the perceived behavioral control that can affect a person's behavior.

2. Professionalism influences the auditor's intention to conduct whistleblowing. It can be interpreted that a high level of professionalism will increasingly encourage the interest of auditors to conduct whistleblowing. This is in line with the prosocial behavior theory that explains professionalism as a beneficial action for the organization.

3. Organizational commitment moderates (strengthens) the relationship between locus of control and the auditor's intention to conduct whistleblowing. It can be interpreted that the high organizational commitment held by auditors influences the interaction between locus of control and the intention of auditors to do whistleblowing. This is in line with the theory of planned behavior which explains that this theory is used to predict certain behavior of individuals

4. Organizational commitment moderates (strengthens) the relationship between professionalism and auditor intentions in conducting whistleblowing. It can be interpreted that the higher the level of organizational commitment an auditor has, it will strengthen the interaction between professionalism and the auditor's intention to conduct whistleblowing. This is in line with the prosocial behavior theory that explains the behavior or actions of members of the organization that provide benefits to the organization.

\section{Reference:-}

1. Ajzen, Icek. 2005. Attitudes, Personality, and Behavior. $2^{\text {nd }}$ Edition. Berkshire. UK: Open University Press McGraw Hill Education. 
2. Ajzen, Icek. 1991. The Theory of Planned Behavior. Organizational Behavior and Human Decision Processes, (Online), Vol. 50, 179-211, (https://www.sciencedirect.com, diakses 2 Januari 2019)

3. Ajzen, Icek. 2006. Constructing a Tpb Questionnaire: Conceptual and Methodologial Considerations. Occasional Paper. (Online) (http://people.umass.edu/aizen/ diakses pada 17 Januari 2019).

4. Allen, N.J. and J.P. Mayer. 1991. The Measurement and Antecedent of Affective, Continuance and Normative Commitment to the Organizational. Jornall of Occupational Psychology.63 (1):1-18.

5. Alkautsar, Muslim. 2014. Locus of Control, Commitment Professional and Dysfunctional Audit Behavior. International Journal of Humanities and Management Sciences IIJHMS) Volume 2.

6. Arens. A. Alvin, Elder, J. Randal, Beasley, S. Mark. 2009. Auditing Assurance Services. Twelve Edition. New Jersey : Pearson.

7. Arfan, Ikhsan. 2010. Akuntansi Keprilakuan. Jakarta: Salemba Empat.

8. Ayu, H. Ester. 2014. Pengaruh Komitmen Profesional dan Locus of Control Auditor Internal terhadap Intensi Melakukan Whistleblowing : Kesadaran Etis Sebagai Variabel Pemoderasi. Tesis. Yogyakarta: Universitas Gadjah Mada.

9. Bagustianto, R dan Nurkholis. Faktor-faktor yang Mempengaruhi Minat Pegawai Negeri Sipil (PNS) untuk Melakukan Tindakan Whistleblowing (Studi pada PNS BPK RI). Jurnal Ilmiah Mahasiswa. Vol 3. No.1 h.1-19.

10. Bariyama, David Kiabel. 2012. Auditor Internaling and Performance of Government Enterprises: A Nigerian Study. Double Blind Peer Reviewed International Research Journal, 12 (6): 1-17.

11. Baron. Byrne. 1994. Social Psychology : Understanding Human Interaction. USA : Needham Heights Allyn and Bacon Inc.

12. Bouville, Mathiew. 2016. Whistle-blowing and Morality. The Journal of Business Ethics (Online), Vol. 20:43; p.1 (http://www.springerlink.com diakses tanggal 18 Januari 2019)

13. Brennan, Niamh., Kelly, John. 2007. A Study of Whistleblowing among Trainee Auditors. British Accounting Review, (Online), Vol. 39 (1), 61-87), (https://papers.ssrn.com diakses tanggal 9 Januari 2019).

14. Catherine F, Ratu. 2017. Pengaruh Sikap, Norma Subyektif, Perceived Behavioral Control, Reward, dan Locus of Control terhadap Intensi Perilaku Whisleblower. Tesis. Lampung: Program Pascasarjana Magister Ilmu Administrasi Fakultas Ilmu Sosial Politik Universitas Lampung

15. Chiu, K. Randy. 2003. "Ethical Judgement, Locus of Control, and Whistleblowing Intention: A Case Study of Mainland Chinese MBA Students". Managerial Auditing Journal, Vol. 17 Issue:9 pp. 581-587.

16. Daivitri, Aai Niyaratih. 2013. Pengaruh Pertimbangan Etis dan Komponen Perilaku Terencana Pada Niat Whistleblowing Internal dengan Locus of Control Sebagai Variabel Pemoderasi. Tesis. Yogyakarta: Universitas Gadjah Mada

17. Dayaksini, Tri., dan Hudaniah. 2013. Psikologi Sosial. Malang: UMM

18. Eisenberg-Berg, N., \& Hand, M. 1979. The relationship of presschoolers' reasoning about prosocial moral con icts to prosocial behavior. Child Development, (Online), Vol. 50, No. 2 (Jun., 1979), pp. 356-363, (http://www.jstor.org, diakses 2 Januari 2019).

19. Elias, 2008. Auditing Student Profesional Commitment and Anticipatory Socialization and Their Relationship to Whistleblowing. JournalManagerial Accounting. Vol. 23, No. 3, 283-294.

20. Garman, Andrew N. 2006. Professionalism. Journal Of Healthcare Management. 51(4)

21. Ghozali, Imam. 2011. Aplikasi Analisis Multivariate Dengan Program SPSS. Semarang: Badan Penerbit Universitas Diponegoro.

22. Gibson, James L., John M. Ivancevich, James H. Donnelly Jr., and Robert Konopaske. 2012. Organization: Behavior, Structure, Processes (14 Edition). New York: McGraw-Hill/Irwin.

23. Gitosudarmo, Indriyo., dan Sudita, I Nyoman. 2008. Perilaku Keorganisasian. Yogyakarta: BPFE-Yogyakarta.

24. Hall, H. Richard. 1968. Professionalization and Bureaucratization. American Sociological Review 33 (February) : 92-104.

25. Hoffman, W. Michael and Robert E. 2008. "A Business Ethics Theory of Whistleblowing”. Journal of Business and Environmental Ethics. Bentley University, Waltham MA. USA, (Online) 45-59 (https://www.bentley.edu/, diakses 10 Januari 2019)

26. Hyatt, T., and D. Prawitt. 2001. Does Congruence Between Audit Structure and Auditors Locus of Control Affect Job Performance?. The Accounting Review 76.

27. Indonesian Corruption Watch. 2019. (https://antikorupsi.org diakses tanggal 12 Januari 2019)

28. Jalil, F. Y. 2012. Pengaruh Komitmen Profesional Auditor terhadap Intensi Melakukan Whistleblowing. Locus of Control sebagai Variabel Pemoderasi. Tesis: Yogyakarta: Universitas Gadjah Mada 
29. Janitra, Wimpi Abirama. 2017. Pengaruh Orientasi Etika, Komitmen Profesional, Komitmen Organisasi, dan Sensitivitas Etis terhadap Internal Whistleblowing. JOM Fakultas Ekonomi, (Online), Vol. 4 No. 1, (https://jom.unri.ac.id, diakses 4 Januari 2019).

30. James. 1984. Whistleblowing System. (Asep Triwahyudi, dkk. 2011) diunduh tahun 2011. http://www.wise.depkeu.go.id

31. Jogiyanto. 2007. Metodologi Penelitian Bisnis : Salah Kaprah dan Pengalaman-pengalaman. Cetakan Pertama. Yogyakarta : BPFE.

32. Kalbers, L and P.T. Forgaty. 1995. Profesionalism and Its Consequences : A Study of Internal Auditors." Journal of Auditing 14, no.1 (Sarasota: Spring 1995)

33. Karmita, Fitriah. 2018. Analisis Kinerja Auditor Melalui Komitmen Profesional dan Whistleblower. Tesis. Makassar: Program Magister Akuntansi Fakultas Ekonomi dan Bisnis Universitas Hasanuddin.

34. Komite SPAP Ikatan Akuntan Indonesia (IAI). 2001. Standar Profesional Akuntan Publik. Jakarta : Salemba Empat.

35. Kreitner, R, dan A Kinicki. 2000. PerilakuOrganisasi, Jakarta: Salemba.

36. Larkin, Joseph M. 1990. Does Gender Affect Auditor CPAs" Performance?, The Women CPA, Spring, pp. 2024.

37. Lekatompessy, J.E. 2003. Hubungan profesionalisme dengan konsekuensinya: komitmen organisasional, kepuasan kerja, prestasi kerja, keinginan berpindah (Studi Empiris di lingkungan Akuntan Publik). Jurnal Bisnis dan Akuntansi. Vol.5 No.1 Hlm. 69-84.

38. Luthans, Fred. 2006. OrganizationalBehavior. 9th Edition. New York: McGrawHill.

39. Mardiasmo. 2002. Akuntansi Sektor Publik. Penerbit: Andi. Yogyakarta

40. Mayer, et al. 1993. Commitment to Organization and Occupations : Extension and Test of a Three-Component Conceptualization. Journal of Applied Psychology Vol. 78 No.4. American Psychological Association.

41. Menesez, Alvaro A. 2008. Analisis Dampak Locus of Control terhadap Kinerja dan Kepuasan Kerja Auditor Internal (Penelitian pada Internal Auditor di Jawa Tengah). Universitas Diponegoro, (Online), Vol. 2 No.1, (http://eprints.undip.ac.id. diakses pada 12 Januari 2019)

42. Miceli, M.P., and Near J., (1991). Blowing the Whistle: The Organizational and Legal Implications for Companies and Employess. New Jersey: Lexington Books.

43. Mowday, et al. 1983. The Measurement of Organizational Commitment. Journal of Applied Psychology Vol. 84. American Psychology Association.

44. Near, J. P. dan M. P. Miceli. 1995. Effective Whistle-blowing. Academy of Management, The Academy of Management Review 20(3), 679-708.

45. Nugroho, Vredy octaviari. 2015. Pengaruh Persepsi Karyawan Mengenai Whistleblowing System terhadap Pencegahan Fraud dengan Perilaku Etis Sebagai Variabel Intervening Pada PT. Pagilaran. Skripsi. Yogyakarta: Fakultas Ekonomi dan Bisnis Universitas Negeri Yogyakarta.

46. Peraturan Menteri Pendayagunaan Aparatur Negara dan Reformasi Birokrasi Republik Indonesia Nomor 11 Tahun 2015 Tentang Road Map Reformasi Birokrasi 2015-2019.

47. Peraturan Pemerintah Republik Indonesia Nomor 79 Tahun 2005 Tentang Pembinaan dan Pengawasan Penyelenggaraan Pemerintah Daerah.

48. Peraturan Presiden Republik Indonesia Nomor 192 Tahun 2014 Tentang Badan Pengawasan Keuangan dan Pembangunan (BPKP).

49. Peter, Yeoh. 2014. Whistleblowing: motivations, corporate self-regulation, and the law. International. Journal of Law and Management, (Online) Vol. 56 Iss 6 pp. 459-474 (www.emeraldinsight.com diakses pada 15 Januari 2019).

50. Read, J. William. 2015. Whistle-blowing to Internal auditors. Managerial Accounting Journal. Vol. 18 Iss 5 pp. 354-362.

51. Robbins, Stephen P. 2002. Prinsip-prinsip Perilaku Organisasi. Edisi kelima. Jakarta: Penerbit Erlangga.

52. Robbins, Stephen P dan Timothy, A. Judge. 2008. Perilaku Organisasi. Buku II, Jakarta: Salemba Empat.

53. Robbins, Stephen P dan Timothy A. Judge. 2011. Perilaku Organisasi. Jakarta: Salemba Empat.

54. Rotter, J.B. (1990). Internal vs External control reinforcement: A case history of a Variable. American Psychologist, (Online), 45(4), 489-493 (psycnet.apa.org, diakses 2 Januari 2019).

55. Nadler, Judy and Schulman. Miriam. 2008. "Whistle-Blowing in the Publik Sector", SCU.EDU. The NCAA and Whistleblowers: 30-40 Years of Wrongdoing and College Sport and Possible Solutions. (online) Vol. XXVIII/Southern Law Journal https://www.scu.edu/ethicts/focus-areas/government-ethics/resources/what-isgovernment-ethicts/whistle-blowing-in-the-public-sector/ diakses tanggal 14 Januari 2019) 
56. Riska. 2017. Pengaruh Profesional Auditor, Orientasi Etika Idealisme, dan Relativisme terhadap Whistleblowing dengan Sensivitas Etis sebagai Variabel Moderating. Makassar: Fakultas Ekonomi dan Bisnis Islam Alauddin Makassar.

57. Rotter, J.B. 1966. Generalized Expectancies for Internal versus External Control of Reinforcement. Psychological Monographs, Vol.80, pp. 1-28

58. Rotter, J.B. (1975). Some problems and misconceptions related to the construct of internal and external control in reinforcement. Journal of Consulting and Clinical Psychology, (Online), Vol. 43, 56-67, (psycnet.apa.org, diakses pada 11 Januari 2019)

59. Sari, Devi Novita., Laksito, Herry. 2014. Profesionalisme Internal Auditor dan Intensi Melakukan Whistleblowing. Diponegoro Journal of Accounting, (Online) Vol 03. No. 03. (http://ejournalundip.ac.id/index.php/accounting diakses tanggal 8 Januari 2019)

60. Sarita, Jena., dan Agustia, Dian. 2009. "Pengaruh Gaya Kepemimpinan Situasional, Motivasi Kerja, Locus of Control terhadap Kepuasan Kerja dan Prestasi Kerja Auditor”. Simposium Nasional Akuntansi XII.

61. Sawyer, B. Lawrence. 2008. Intennal Auditing Edisi Lima Jakarta: Salemba Empat.

62. Sears, David O. 1991. Psikologi Sosial, jilid II. Jakarta : Erlangga.

63. Sekaran, Uma \& Bougie, Roger. 2016. Research Method for Business. A skill building Approach. Seventh Edition. Wiley.

64. Siegel, G. \& Helene, R.M. 1989. Behavioral Accounting. Ohio:South-Western Publishing Co. Cincinnatti.

65. Staub, E. 1978. Positive Social Behavior and Morality: social and personal influences. New York: Academy Press.

66. Sugiyono. 2013. Statistika Untuk Penelitian. Bandung: Alfabeta.

67. Suharyanto dan Iryanto, Tata. 1996. Kamus Besar Bahasa Indonesia. Surabaya: Indah

68. Sujarweni, V. Wiratna. 2015. Metodologi Penelitian Bisnis dan Ekonomi.Yogyakarta: Pustaka Baru Press.

69. Sunyoto, Danang. 2011. Analisis Regresi untuk Uji Hipotesis. Yogyakarta: Caps

70. Surat Edaran Menteri Pendayaan Aparatur Negara dan Reformasi Birokrasi Nomor 8/M.PAN-RB/06/2012 Tentang Sistem Penanganan Pengaduan Whistleblower System) Tindak Pidana Korupsi di Lingkungan Kementrian/Lembaga dan Pemerintah Daerah

71. Transparancy.org.2018 (http://transparancy.org/country/IDN\#, diakses tanggal 11 Januari 2019)

72. Tuanakotta, Theodorrus M. 2011. Berpikir Kritis dalam Auditing. Jakarta: Salemba Empat.

73. United Nations Development Programme (UNDP). 1997. Governance for sustainable human development : A UNDP policy document. New York:Oxford University Press.

74. Wiener, Y. 1982. "Commitmenr in Organizations: A Normative View" , Academy of Management Review. Vol. 7 No 3. Pp. 418-428.

75. Yanti, Harti Budi., Hasnawati. 2017. Kompetensi Moral dan Intensi Whistleblowing. Jurnal Media Riset Akuntansi, Auditing, dan Informasi, (Online), Vol. 17 (2), 2017, 131-144. (ejurnal.upi.edu, diakses 4 Januari 2019)

76. Zoraifi, Renata. 2005. Pengaruh Locus of Control, Tingkat Pendidikan, Pengalaman Kerja, dan Pertimbangan Etis terhadap Perilaku Auditor dalam Situasi Konflik Audit. Jurnal Akuntansi dan Bisnis. (Online) Vol. 5, No.1 (http://eprints.umk.ac.id diakses 9 Januari 2019). 